\title{
DESAIN PENGEMBANGAN BAHAN AJAR DIGITAL BERBATUAN APLIKASI COMIC LIFE 3 PADA MATA KULIAH MEDIA PEMBELAJARAN ANAK USIA DINI
}

\author{
THE DESIGN OF DEVELOPING DIGITAL MATERIALS WITH ROCKS \\ APPLICATIONS \\ COMIC LIFE 3 AT EARLY CHILDHOOD LEARNING MEDIA COURSES
}

\section{BADRI MUNAWAR}

\author{
Sekolah Tinggi Keguruan dan IImu Pendidikan Syekh Manshur \\ Jalan Raya Labuan Km. 5 Kadulisung, Pandeglang \\ Ponsel : 085895872346 \\ Surel : badri.munawar02@gmail.com
}

\begin{abstract}
Abstrak
Penelitian ini bertujuan untuk melihat hasil efektivitas dari penggunaan Comic Life 3 dalam proses pembelajaran. Penggunaan Gambar komik dalam proses pembelajaran adalah untuk memperkaya imaginasi dan kreativitas mahasiswa di era Teknologi. Permasalahan yang terjadi pada proses pembelajaran di PGPAUD adalah minimnya akses untuk mengoperasikan bahan ajar berbasis digital, meskipun sudah tersedia sarana seperti laptop atau projektor. Proses pembelajaran yang dilaksanakan dalam pendidikan anak usia dini yang di-blanded bermain dengan pembelajaran memakai Gambar komik akan memudahkan mahasiswa atau calon guru memperkaya bahan ajar. Peneliti menggunakan model ADDIE (Analysis, Design, Develop, Implementation, dan Evaluation). Subjek penelitian yaitu 20 Mahasiswa PGPAUD di STKIP Syekh Manshur. Hasil dari penelitian yang dilakukan pada tahapan Evaluation menunjukkan keberhasilan sebanyak $87.7 \%$ yang dapat dikategorikan sangat tinggi. Bahan ajar digital yang menggunakan bantuan aplikasi Comic Life 3 dianggap efektif untuk digunakan oleh Mahasiswa PGPAUD.
\end{abstract}

Kata kunci: Bahan Ajar, Media Pembelajaran, Comic Life 3

\begin{abstract}
The research aims to see the results of the effectiveness of the use of Comic Life 3 in the learning process. The use of animated drawings in the learning process is to enrich the imagination and creativity of students in the technology era. The problems that occur in the learning process in the PGPAUD are the lack of access to operate digital-based materials, although there are tools such as laptops or projectors. The learning process carried out in the early childhood education that was in blanded play with the learning of animated drawings will make it easier for students or prospective teachers to enrich the teaching materials. Researchers use ADDIE models (Analysis, Design, Develop, Implementation, and Evaluation). The research subject is 20 PGPAUD students at STKIP Sheikh Manshur. The results of the research conducted in the Evaluation stage showed a success of $87.7 \%$ which can be categorized very high. Digital teaching materials using the help of Comic Life 3 application are considered effective for use by PGPAUD students.
\end{abstract}


Keywords: teaching materials, learning media, Comic Life 3

\section{PENDAHULUAN}

Perkembangan Teknologi Informasi dan Komunikasi (TIK) telah mempengaruhi penggunaan berbagai jenis media dalam proses pembelajaran. Pengajar diharapkan mampu menggunakan media tersebut secara efektif dan efisien dalam proses pembelajaran. Selain itu, pengajar juga diharapkan dapat menggunakan berbagai alat-alat yang murah, efisien, mampu dimiliki kampus, baik yang dibuat sendiri oleh pengajar, maupun alat-alat yang sudah tersedia yang dimiliki kampus, serta tidak menolak kemungkinan menggunakan alat-alat yang sesuai dengan tuntutan perkembangan kemajuan teknologi dalam pembelajaran. Pendidikan menjadi salah satu sektor yang juga mendapatkan tantangan tersebut, berkaitan dengan hal itu tenaga pendidik sebagai unsur atau pengguna langsung dalam proses pendidikan akan menghadapi tantangan kemajuan teknologi, meskipun mahasiswa adalah subjek yang utama yang menjadi sasaran utama dari setiap perubahan. Perkembangan dunia pendidikan akan selalu beriringan dengan perkembangan teknologi seperti di era
Revolusi Industri 4.0 yang memiliki tujuan untuk mempermudah proses pekerjaan melalui otomatisasi dan akurasi yang tinggi. Selain itu era revolusi industri 4.0 memiliki ciri khas dalam kecepatan teknologi di berbagai aspek kehidupan, bersamaan dengan tuntutan yang berkaitan dengan masalah mutu atau kualitas. Demikian halnya dalam konteks pendidikan, peranan teknologi cukup penting untuk meningkatkan pendidikan agar bisa setara dan bersaing dengan kebutuhan industri.

Dunia pendidikan adalah titik sentral dalam perkembangan sumber daya manusia yang berkualitas, untuk itu sektor pendidikan dituntut lari dan berkembang menyesuaikan dengan kondisi yang ada. Penyesuaian itu dimaksudkan agar setiap pendidik harus bisa adaptif terhadap arus teknologi yang semakin deras, agar sumber daya manusia yang dipersiapkan sejak dini dapat menghadapi tantangan belum pernah dialami sebelumnya. Persiapan dalam menghadapi tantangan tersebut tentunya guru perlu meningkatkan kompetensi personal yang akan di kolaborasikan dengan kemampuan mengelola bahan ajar berbasis teknologi informasi. Selain itu, untuk 
menyesuaikan perubahan cara kerja di era teknologi perlu optimalisasi bahan ajar yang digunakan selama proses pendidikan. Sehingga guru yang memiliki kompetensi khusus seperti kreativitas, berpikir kritis, dan metakognitif akan mudah mengoperasikan pembelajaran yang berbasis teknologi di Abad 21 (B Boholano, 2017).

Mahasiswa memliki rasa keingintahuan akan teknologi baru dengan sangat tinggi. Saat ini banyak mahasiswa yang justru memiliki perangkat telepon atau telepon pintar dengan spesifikasi yang lebih baik, namun belum maksimal dalam penggunaannya. Banyak mahasiswa yang memakai perangkat itu hanya sekadar untuk pergaulan semata belum banyak yang merambah pada upaya untuk meningkatkan pengetahuan dalam pendidikan. Untuk merealisasikan pemikiran di atas, diperlukan langkah-langkah konkret. Salah satunya dengan menciptakan pembelajaran yang efektif dan berkualitas, namun dalam menciptakan pembelajaran tersebut, sering mengalami kendala misalnya pada saat model pembelajaran konvensional dirasa kurang efektif untuk diterapkan dan saat pengajar dan mahasiswa berhalangan hadir atau ada kegiatan penting yang mengharuskan meninggalkan proses pembelajaran. Untuk mengantisipasi hal tersebut maka diperlukan alternatif model pembelajaran, salah satunya dengan menggunakan Comic Life 3 yang dapat menjadi perangsang bagi kreativitas dan mengembangkan kemampuan dedaktik mahasiswa PGPAUD dalam membuat Bahan Ajar.

\section{KAJIAN TEORETIK}

Media adalah suatu alat perantara atau pengantar yang berfungsi untuk menyalurkan pesan atau informasi dari suatu sumber kepada penerima pesan. Dalam menyalurkan pesan atau informasi harus secara efektif dan efisien.

$\begin{array}{ccc} & \text { Pembelajaran merupakan } \\ \text { suatu kegitatan yang melibatkan }\end{array}$ seseorang dalam upaya memperoleh pengetahuan, keterampilan dan nilainilai positif dengan memanfaatkan berbagai sumber untuk belajar. Pembelajaran dapat melibatkan dua pihak yang saling berinteraksi.

Bahan ajar merupakan salah satu perangkat penting pada saat guru memberikan materi karena bahan ajar dimaksudkan sebagai sesuatu yang bisa digunakan untuk mendapatkan timbal balik pesan dari 
pengirim ke penerima pesan. Sehingga keberadaan bahan ajar dapat merangsang pikiran, perasaan, minat serta perhatian peserta didik sehingga terjadi proses belajar mengajar. Penggunaan bahan ajar merupakan sebagai bahan yang berfungsi untuk membantu pendidik dalam melaksanakan proses pembelajaran dikelas. Bahan yang dimaksud ini bisa berupa bahan tertulis dan tidak tertulis. Dalam konteks lain bahan ajar akan bersinggungan dengan media pembelajaran yang semestinya memiliki fungsi sebagai alat bantu kegiatan belajar mengajar yang turut mempengaruhi, motivasi, kondisi, dan lingkungan belajar. Bahkan dalam kasus tertentu, media pembelajaran dapat memberikan perlindungan ketika siswa harus mempelajari materi yang berbahaya seperti api atau sungai (Febiharsa \& Djuniadi, 2018).

Sebagai upaya pengenalan bahan ajar yang berbasis teknologi informasi tentu diperlukan adanya pengembangan bahan ajar yang mudah dipahami oleh peserta didik. Pada penelitian penggunaan teknologi dalam pendidikan anak usia dini oleh Arnada \& Putra (2018) mengungkapkan tentang pentingnya penggunaan teknologi di sekolah baik digunakan sebagai bahan ajar maupun media informasi sebagai salah satu sarana untuk memperkenalkan perkembangan teknologi kepada anak usia dini.

Tujuan lain dikembangkannya bahan ajar berbasis digital agar proses belajar lebih fleksibel. Bahan ajar yang berbasis teknologi saat ini sudah cukup beragam dengan memunculkan visual, gambar, video, juga komik yang dimaksudkan agar dapat menyampaikan pesan pembelajaran terhadap peserta didik. Bahan ajar berbantuan video memiliki keunggulan penyampaian informasi yang dapat menampilkan visualisasi dari realitas yang ada. Namun kondisi di lapangan menunjukkan bahwa penggunaan video di sekolah khususnya di PAUD, belum banyak dimanfaatkan. Hal ini disebabkan oleh beberapa faktor, di antaranya adalah kemampuan pendidik dalam memproduksi media pembelajaran. COMIC LIFE 3 merupakan salah satu inovasi yang dapat dijadikan alternatif untuk media pembelajaran. Aplikasi tersebut lebih mudah untuk dibuat dan diaplikasikan oleh tenaga pendidik, dimana tersedia dengan mudah di laman internet. COMIC LIFE 3 merupakan salah satu aplikasi yang 
dapat membuat media pembelajaran berupa komik.

Bahan ajar digital yang merupakan inovasi baru dalam dunia pendidikan sehingga dapat menampilkan media informasi yang unik.

Banathy (dalam Gatot, 2008) menyatakan

bahwa

pengembangan bahan ajar adalah suatu proses yang sistematis dalam mengidentifikasi, mengembangkan, dan mengevaluasi isi dan strategi pembelajaran yang diarahkan untuk mencapai tujuan pembelajaran secara lebih efektif dan lebih efisien. Menggunakan aplikasi COMIC LIFE 3 pada saat kegiatan belajar mengajar kepada peserta didik Anak Usia Dini akan membuat lebih interaktif dan menarik. Seperti yang telah dikatakan dalam penelitian Sudaryono et al. (2018) bahwa dengan kehadiran komik yang interaktif sebagai sebuah media dalam proses kegiatan pembelajaran pada anak usia dini bisa mempermudah dalam pengenalan jenis-jenis hewan serta dengan adanya komik mampu meningkatkan minat belajar peserta didik. Dalam koteks lain proses belajar mengajar bisa lebih bervariasi dan menyenangkan. Melihat proses pembelajaran yang dilaksanakan di pendidikan anak usia dini harus dikombinasikan dengan bermain, tentu akan lebih mudah jika pembelajaran tersebut menggunakan media yang sesuai. Pemanfaatan teknologi aplikasi yang memvisualisasikan komik di bidang pendidikan anak usia dini merupakan salah satu upaya untuk menghadirkan lingkungan virtual dalam pengenalan objek-objek yang belum mungkin dihadirkan di ruang kelas.

\section{METODE PENELITIAN}

Penelitian ini menggunakan metode pengembangan, hal itu dimaksudkan untuk menghasilkan produk berupa bahan ajar digital dengan model pengembangan ADDIE. Model ADDIE dalam mendesain sistem instruksional menggunakan pendekatan sistem. Esensi dari pendekatan sistem adalah membagi proses perencanaan pembelajaran ke beberapa langkah, untuk mengatur langkah-langkah ke dalam urutan-urutan logis, kemudian menggunakan output dari setiap langkah sebagai input pada langkah berikutnya Januszewski and Molenda (2008). Analyze (Analisis), sebuah proses menganalisis kondisi dan spesifikasi media pembelajaran yang diperlukan peserta didik PAUD. Tahap 
ini merupakan proses menelaah bahan ajar yang sudah pernah digunakan kemudian untuk dikembangkan ke dalam produk baru. Selain itu kegiatan analisis ini berkaitan dengan mengidentifikasi bahan ajar yang sesuai dengan sasaran peserta didik, tujuan belajar dan isi materi yang ada pada bahan ajar tersebut. Design Pada tahap perancangan, peneliti sudah membuat produk awal atau rancangan produk yang disesuaikan dengan analisis pada tahap sebelumnya. Dalam hal ini prototype berupa rancangan bahan ajar untuk materi alam semesta di Pendidikan Anak Usia Dini. Develop, pada tahapan ini disusun konten materi, rekaman komik berdasarkan desain yang sudah ditentukan dan divalidasi oleh ahli dan dilakukan develop testing. Validasi ahli digunakan sebagai saran perbaikan dari rancangan produk yang telah disusun. Implementation Pada tahap ini kegiatan yang dilakukan adalah validation testing. Pada tahap validation testing, produk yang sudah direvisi pada tahap pengembangan (develop) kemudian diimplementasikan pada sasaran sesungguhnya dalam skala besar. Hasil dari implementasi pada lingkup pengembangan akan dijadikan landasan pada pelaksanaan tahap evaluasi Evaluation pada saat tahap implementasi dilakukan pengukuran ketercapaian tujuan. Pengukuran ini dilakukan untuk mengetahui nilai guna efektivitas dari produk yang dikembangkan setelah produk diimplementasikan. Adapun skema tahapan pengembangan bahan ajar digital dengan menggunakan model ADDIE adalah sebagai berikut:

Teknik pengumpulan data awal dilakukan melalui pengamatan mengenai kebutuhan media yang digunakan oleh guru selama pembelajaran, pengamatan dilakukan sebagai dasar dalam penentuan pengembangan bahan ajar digital. Adapun pelaksanaan pengamatan pada saat kegiatan belajar mengajar di Pendidikan Anak Usia Dini. Selain itu teknik pengumpulan data yang dilakukan adalah menggunakan angket yang diberikan kepada ahli media untuk mengetahui kelayakan media pembelajaran. Angket yang diberikan kepada ahli berisi tentang penilaian kesesuaian konten, kelayakan media, daya tarik, dan manfaatnya dengan rumus penilaian sebagai berikut: 


$$
\text { Hasil }=\frac{\begin{array}{c}
\text { Skor yang } \\
\text { diperoleh }
\end{array}}{\text { Skor Maksimal }} \times 100 \%
$$

Tabel 1. Kelayakan Produk

\begin{tabular}{|c|c|c|}
\hline $\begin{array}{c}\text { Tingkat } \\
\text { Pencapaian }\end{array}$ & Kategori & Keterangan \\
\hline $85 \%-100 \%$ & $\begin{array}{l}\text { Sangat } \\
\text { Baik }\end{array}$ & $\begin{array}{l}\text { Tidak } \\
\text { direvisi }\end{array}$ \\
\hline $75 \%-84 \%$ & Baik & $\begin{array}{l}\text { Tidak } \\
\text { direvisi }\end{array}$ \\
\hline $65 \%-74 \%$ & Cukup & Revisi \\
\hline $55 \%-64 \%$ & Kurang & Revisi \\
\hline $0 \%-54 \%$ & $\begin{array}{l}\text { Kurang } \\
\text { Sekali }\end{array}$ & Revisi \\
\hline
\end{tabular}
Bahan Ajar Digital Berbantuan Komik COMIC LIFE 3

Penelitian ini melibatkan 30 guru sebagai subjek untuk melihat ketercapaian tujuan pemanfaatan dengan menggunakan angket berupa skala yang diberikan kepada guruguru di PAUD tentang ketercapaian tujuan implementasi bahan ajar digital COMIC LIFE 3 . Keterlibatan guru merupakan bagian penting karena mereka sebagai user utama yang bersentuhan langsung dengan media pembelajaran. Proses penilaian ketercapaian ini bersamaan dengan tahapan implementation kemudian pada akhir uji coba dilakukan evaluasi berupa angket dengan rumus sebagai berikut:

$$
\mathrm{f}=\begin{gathered}
\begin{array}{c}
\text { Jumlah } \\
\text { persentase } \\
\text { indikator }
\end{array} \\
\text { Jumlah indikator }
\end{gathered}
$$

Tabel 2. ketercapaian implementasi Produk Bahan Ajar Digital Berbantuan Komik COMIC LIFE 3

\begin{tabular}{cc}
\hline Tingkat Pencapaian & Kategori \\
\hline $85 \%-100 \%$ & Sangat Tinggi \\
$75 \%-84 \%$ & Tinggi \\
$65 \%-74 \%$ & Sedang \\
$55 \%-64 \%$ & Rendah \\
$0 \%-54 \%$ & Sangat \\
& Rendah \\
\hline
\end{tabular}

\section{HASIL DAN PEMBAHASAN}

Berdasarkan hasil observasi dan pengamatan kondisi di lapangan menunjukkan bahwa penggunaan video di sekolah khususnya di PAUD, belum banyak dimanfaatkan dengan baik. Hal ini disebabkan oleh beberapa faktor, di antaranya adalah kemampuan pendidik dalam memproduksi video pembelajaran serta fasilitas berupa pengebangan aplikasi yang belum cukup memadai untuk semua kegiatan pembelajaran. 
Sebanyak sepuluh sekolah yang dilakukan observasi lapangan belum menggunakan bahan ajar digital berupa video komik. Setelah dilakukan pendalaman terhadap guru tentang keterbatasan penggunaan bahan ajar digital adalah karena tidak semua mampu secara mandiri memproduksi bahan ajar yang sesuai tema kegiatan dengan menggunakan teknologi digital, keterbatasan lain adalah ketersediaan software yang mudah digunakan untuk memproduksi bahan ajar tersebut. Selain itu dalam membuat bahan ajar digital berupa komik memerlukan waktu yang cukup panjang, hal ini menjadi hambatan signifikan ketika guru membuat setiap tema dari bahan ajar tersebut.

Temuan di lapangan pendidik lebih banyak memanfaatkan bahan ajar berupa buku dan alat peraga edukatif lainnya. Penggunaan yang kurang bervariasi menyebabkan kurangnya ketertarikan peserta didik. Perihal sarana prasarana teknologi dalam pembelajaran beberapa sekolah sudah memiliki sarana yaitu LCD proyektor dan aliran listrik di setiap kelas. Akan tetapi pada konteks pemanfaatan, pendidik-pendidik di sekolah tidak menggunakannya media teknologi dan alat yang ada sebagai media pembelajaran dengan alasan penggunaannya yang sulit. Seperti halnya LCD Proyektor hanya disimpan di dalam lemari dan kurang pemanfaatannya dalam proses pembelajaran. Sekalipun digunakan tampilan materi hanya berupa gambar yang memberikan kesan kurang menarik untuk peserta didik.

Berdasarkan hasil analisis tersebut, setidaknya diperlukan formulasi khusus atau bantuan berupa bahan ajar digital untuk digunakan sehingga dapat membantu menstimulasi guru membuat gagasan baru tentang bahan ajar tersebut. Agar kemudian, ke depan guru sudah terbiasa menggunakan bahan ajar digital sesuai dengan kebutuhan perkembangan anak. Berdasarkan temuan yang ada, bahan ajar berbasis digital dan komik relevan dalam meningkatkan mutu sumber daya manusia di era digitalisasi. Berdasarkan hasil analisis tersebut maka diperlukan pembuatan bahan ajar komik berbantuan aplikasi COMIC LIFE 3 .

Setelah melakukan analisis kebutuhan pembelajaran, selanjutnya pada tahapan Design atau pengembangan, pada tahapan ini dilakukan proses pemilihan aplikasi yang relevan dan pembuatan komik yang akan digunakan untuk bahan 
ajar. Tahapan desain merupakan ranah teknis merencanakan prototipe bahan ajar, adapun skema yang dilakukan adalah melalui beberapa langkah: Pertama, menentukan aplikasi yang akan digunakan yaitu COMIC LIFE 3 yang tersedia di peramban, penggunaan aplikasi ini sebagai salah satu langkah mempermudah penggunaan karena memiliki fitur yang lengkap. Pengguna dapat mengombinasikan gambar dan suara baik jenisnya infographic, tipographic, 2D maupun 2,5D. Langkah Kedua adalah, mempersiapkan materi kegiatan yang akan dilaksanakan seperti materi pengenalan alam semesta yang disesuaikan dengan rencana pembelajaran. Setelah itu dirancang gambar-gambar apa saja yang akan di muat dalam tampilan komik seperti manusia, alam semesta dan binatang.

Tahapan develop lebih banyak berkaitan dengan proses memproduksi dari skema dan desain yang sudah dilakukan sebelumnya. Penggunaan aplikasi COMIC LIFE 3 dapat dilakukan dengan mudah melalui peramban internet secara online, dengan begitu setiap orang dapat dengan mudah mengakses COMIC LIFE 3 di perangkat komputer. Dalam tahapan ini pengguna memerlukan koneksi internet yang stabil agar pada saat pengoperasiannya tidak menemukan kendala. Secara spesifik penggunaan alat pada saat produksi hanya menggunakan personal komputer atau laptop, serta jaringan internet yang cukup memadai.

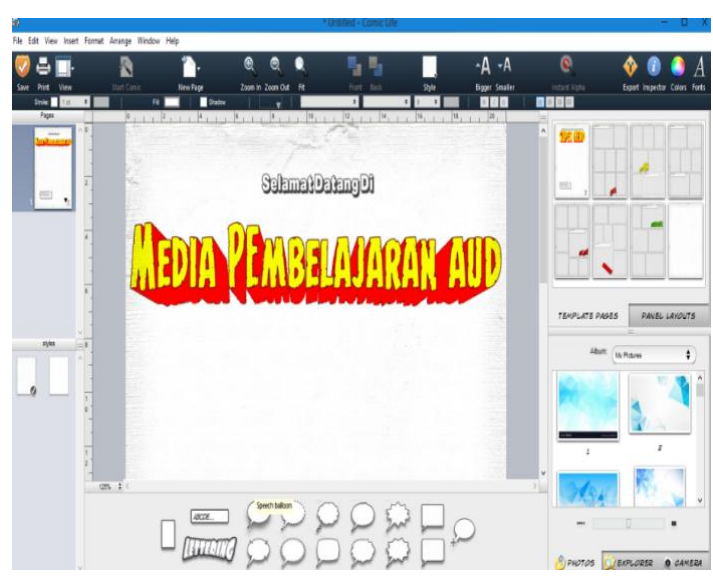

Gambar 1. Proses Pembuatan COMIC LIFE 3

Proses pengembangan bahan ajar digital berbantuan aplikasi COMIC LIFE 3 memiliki beberapa langkah. Adapun yang pertama dilakukan produksi berdasarkan gagasan atau desain yang sudah disediakan. Pada tahapan produksi bahan ajar tersebut secara bersamaan dilakukan juga pencarian bahan yang akan terapkan pada video komik seperti gambar, dan template yang menarik. Template dan gambar di upayakan untuk menyesuaikan dengan karakter pendidikan anak usia 
dini yang ceria dan penuh warna, selain disesuaikan pula dengan tema kegiatan. Dalam proses produksi komik ini mengacu pada tema alam semesta dengan demikian gambargambar dan template yang gunakan seputar alam semesta. Setelah pencarian bahan-bahan yang akan digunakan tahapan kedua membuat komik di aplikasi COMIC LIFE 3. Setelah proses pembuatan komik maka selanjutnya dapat di export dan di publikasikan ke media sosial, atau di tayangkan pada kegiatan pembelajaran dengan bantuan alat projektor.

Setelah proses produksi selesai dilakukan proses peninjauan kelayakan expert appraisal bahan ajar yang dilakukan oleh pakar media dengan hasil $82,5 \%$ dengan kriteria baik. Berdasarkan kriteria tersebut pada peninjauan expert appraisal menghasilkan kategori "tidak perlu di revisi" setelah itu dilanjutkan pada tahap uji coba terbatas. Adapun beberapa saran yang sampaikan oleh ahli untuk pengembangan bahan saja ini adalah perlunya kesesuaian warna yang menarik perhatian peserta didik PAUD, karena anak usia dini lebih tertarik pada warna-warna yang ceria dan cerah, serta kreativitas pemilihan gambar-gambar yang sesuai dengan karakter anak usia dini. Semua saran yang telah disampaikan kemudian dilakukan perbaikan agar menghasilkan bahan ajar yang sesuai kebutuhan. Sedangkan pada tahapan developmental testing atau uji coba pada jumlah sasaran terbatas menghasilkan rata-rata $8,0 \%$ dari 10 uji coba. Hasil ini berada pada kategori tinggi meskipun pada beberapa bagian seperti pemilihan gambar dan warna masih memiliki kategori sedang. Berdasarkan expert appraisal dan developmental testing akan dilakukan perbaikan agar mendapatkan hasil yang sesuai dengan harapan.

Pada tahapan implementation lebih menekankan pada penggunaan bahan ajar yang sudah di produksi. Pada tahapan ini sudah dilakukan perbaikan berdasarkan saran yang sudah diberikan pada saat proses expert appraisal. Adapun media tersebut di implementasikan dalam skala besar kepada 30 guru PAUD di Kabupaten Pandeglang. Hasil dari implementasi tersebut kemudian akan dilanjutkan pada tahapan evaluasi.

Proses evaluasi yang dilakukan secara bersamaan dengan implementasi dimaksudkan agar pengguna bahan ajar digital dapat merasakan langsung nilai guna bahan 
ajar dan aplikasi. Sebanyak 30 orang guru telah di berikan tanggapan untuk efektivitas penggunaan bahan ajar tersebut. Hasil dari evaluasi menunjukkan keberhasilan sebanyak $85.2 \%$ yang dapat dikategorikan sangat tinggi, hal ini menunjukkan peningkatan dari hasil uji coba terbatas yang dilakukan kepada guru PAUD pada masa developmental testing. Kenaikan tersebut berdasarkan tindak lanjut dan saran perbaikan bahan ajar yang bersifat minor seperti kualitas gambar, komik, dan pemilihan warna. Meskipun demikian kategori "tampilan menarik" pada skala evaluasi mendapatkan skor terendah dengan rata-rata skor 4 , untuk itu perlu dilakukan perbaikan kembali pada tahapan pengembangan selanjutnya. Selain itu kategori "dapat menarik perhatian peserta didik" perlu menjadi perhatian khusus, karena berdasarkan pengamatan peserta didik banyak yang kurang memperhatikan komik. Berdasarkan temuan ini maka diperlukan bahan ajar yang tidak hanya mempermudah pengoperasian saja, tetapi perlu memerhatikan bahan ajar yang menarik perhatian. Meskipun demikian "tingkat kesesuaian bahan ajar digital dengan tema" mendapatkan rata-rata skor paling tinggi.

Berdasarkan hasil penelitian yang telah dilakukan, pengembangan bahan ajar digital berbantuan aplikasi COMIC LIFE 3 menujukan ketercapaian yang sangat tinggi. Dapat diartikan media pembelajaran tersebut efektif untuk dioperasionalkan oleh guru untuk menunjang dan mempermudah pembelajaran. Penelitian ini senada dengan Febiharsa \& Djuniadi (2018) bahwa media pembelajaran terutama materi pengenalan lingkungan alam dapat digunakan secara mudah untuk guru dan peserta didik. Media pembelajaran atau bahan ajar selain untuk mentransformasi materi kepada peserta didik dan mencapai perkembangannya juga dapat membantu guru mengembangkan kreativitas membuat bahan ajar yang unik dan menarik. Bahan ajar yang monoton dapat memengaruhi gairah dan motivasi peserta didik yang kurang maksimal, sehingga mencapai perkembangan yang diharapkan. Berdasarkan penelitian yang telah dilakukan dalam pengembangan bahan ajar digital melalui video dapat meningkatkan perkembangan kognitif peserta didik (Yaswinda et al., 2019). Melihat pentingnya bahan ajar 
terhadap kemampuan peserta didik untuk itu guru harus mampu memanfaatkan bahan ajar digital untuk memperlancar kegiatan pembelajaran dan juga dapat merangsang peserta didik untuk aktif. Sehingga guru sebisa mungkin memerlukan media dan bahan ajar yang bervariasi baik yang bersifat digital maupun bahan yang ada di sekitar lingkungan.

Penelitian serupa yang telah dilakukan tentang penggunaan bahan ajar digital lebih banyak berfokus terhadap pencapaian peserta didik. Seperti yang telah dilakukan oleh Agung et al., (2020) bahwa bahan ajar berbasis komik dapat menunjang pencapaian kognisi anak usia dini. Tidak jauh berbeda dengan penelitian yang dilakukan oleh Ansori \& Yuliansyah (2018) bahan ajar yang menggunakan komik bertujuan untuk meningkatkan kemampuan pemahaman anak. Meskipun demikian berdasarkan hasil temuan lain dalam penelitian ini, bahwa bahan ajar digital belum mampu menarik perhatian peserta didik secara utuh. Artinya dalam konteks kemasan belum memiliki daya tarik untuk anak. Sedangkan keberadaan media ajar digital merupakan bagian penting pembelajaran, untuk itu sebisa mungkin bahan ajar dapat memenuhi unsur ramah anak dan menarik perhatian anak. Seperti yang telah diungkapkan oleh Mahardhika (2015) bahwa bahan ajar digital semestinya berfokus pada kemudahan peserta didik dalam mencerna materi, dimana artinya media pembelajaran tersebut dapat menarik perhatian peserta didik. Agar kemudian bahan ajar tidak hanya sebatas untuk menarik perhatian peserta didik, tetapi juga dapat membantu pencapaian perkembangan seperti yang telah dikemukakan dalam penelitian Ansadena \& Doriza (2015) bahwa membuat bahan ajar perlu memperhatikan banyak aspek sepeti moral dan perkembangan anak. Hanya saja, kurangnya minat dan fokus peserta didik terhadap media yang ditampilkan dapat dilakukan dengan pendekatan guru terhadap siswa yang lebih intensif saat pembelajaran (Yasa et al., 2015) Tabel 3. Hasil dari Pengembangan Bahan Ajar Menggunakan Comic Life 3

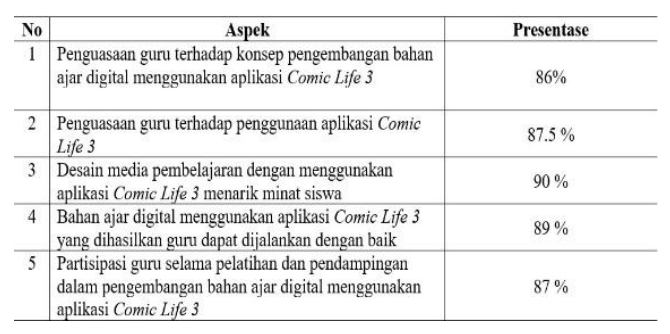


Hasil dari pengembangan bahan ajar menggunakan COMIC LIFE 3 guru dapat lebih mudah mengoperasikan, karena cara kerja yang cukup mudah dan hanya memerlukan peralatan seperti laptop dan projektor. Kemudian guru dapat memutar komik tersebut sambil menirukan suara atau bernyanyi sesuai dengan yang ditampilkan pada komik. Proses ini tentunya merupakan kerja kreatif guru PAUD untuk menyongsong masa pendidikan yang semakin maju. Untuk itu tenaga pendidik PAUD mesti menyesuaikan perkembangan zaman dalam mengimplementasikan pengajaran, metode, model, termasuk bahan ajar. Era pendidikan yang sudah memasuki Abad ke-21 yang ditandai dengan kehidupan berbasis teknologi dan digital, serta pendidikan yang menyesuaikan era Industri 4.0 mesti di sambut positif dengan mempersiapkan kompetensi pedagogik terbarukan. Berbagai strategi mempersiapkan peserta didik yang mampu bertahan di era disrupsi merupakan pekerjaan yang sangat penting, seperti halnya strategi persiapan literasi bagi anak usia dini diperlukan penunjang media yang memadai (Zahro et al., 2019). Untuk memenuhi kebutuhan terebut sebagai guru di PAUD mesti mempersiapkan diri melalui pelatihan pengembangan kemampuan literasi teknologi (Hapsari et al., 2018).

\section{SIMPULAN}

Berdasarkan hasil penelitian yang telah dilakukan, penggunaan bahan ajar berupa komik yang dibuat menggunakan COMIC LIFE 3 efektif membantu guru dalam penyampaian materi lingkungan alam. Berdasarkan evaluasi untuk efektivitas penggunaan komik menunjukkan keberhasilan sebanyak $85.2 \%$ jika dikategorikan berada pada level kegunaan yang tinggi. Untuk mendapatkan kategori ini pengembang telah melakukan perbaikan-perbaikan dari hasil expert appraisal dan development testing meski pada hasil yang di rekomendasikan tidak perlu di revisi, tetapi dirasa cukup perlu adanya perbaikan dalam beberapa konten maka pengembang melakukan perbaikan. Hasil akhir dari evaluasi atas efektivitas penggunaan bahan ajar komik menggunakan COMIC LIFE 3 didukung kuat oleh hasil temuan bahwa tenaga pendidik merasa konten komik dengan materi yang disampaikan sudah sesuai serta mudah dioperasikan. Meskipun pada sisi visual yang kurang menarik 
perhatian anak perlu diberikan perhatian khusus, karena secara angka bagian ini merupakan aspek yang lemah meski masih dalam kategori tinggi. Untuk itu perlu di kemas dengan gaya dan model pembelajaran yang menarik perhatian anak, agar tidak kehilangan fokus saat proses penyampaian materi.

\section{DAFTAR PUSTAKA}

Agung, I. G., Lawe, R., \& Ahmad, A. Komik sebagai Media Pendidikan Karakter Berbasis Tri Kaya Parisudha untuk AnakAnak. 35, 242-249. 2020

Ansadena, N., \& Doriza, S. Pengembangan Media Pembelajaran Pola Asuh Kecerdasan Moral Anak Berbasis Video. Jurnal Kesejahteraan Keluarga Dan Pendidikan, 2, 114-121. https://doi.org/DOI:

doi.org/10.21009/JKKP.022.09, 2015

Ansori, N., \& Yuliansyah, $\mathrm{H}$. Perancangan Media Pembelajaran Manfaat Enam Jenis. 5(1), 35-44, 2018.

Arnada, E. Z., \& Putra, R. W. Implementasi Multimedia Interaktif pada PAUD Nurul Hikmah sebagai Media
Pembelajaran. Jurnal Idealis, 1, 393-400, 2018.

B Boholano, H. Smart Social Networking: 21st Century Teaching and Learning Skills. Research in Pedagogy, 7(1), 21-29.

https://doi.org/10.17810/2015.45 , 2017.

Darling-Hammond, L. Constructing 21 st-century teacher education. Journal of Teacher Education, $57(3)$, 300-314. https://doi.org/10.1177/0022487 $105285962,2006$.

Dick and Carey The Sistematic Design of Instruction Fourth Edition;Harper Collins College Publisher, 1996.

Febiharsa, D., \& Djuniadi. Pengembangan Media Pembelajaran Interaktif 3 Dimensi untuk Pembelajaran Materi Pengenalan Lingkungan Pada Anak Usia Dini di Indonesia . Journal of SECE (Studies in Early Chilhood Education), 75-84, 2018.

Hapsari, A., Novitasari, R., \& Wahyuningsih, $H$. Pelatihan Literasi Sumber dan Bahan Belajar di Internet bagi Guru PAUD di Kecamatan Ngaglik, Sleman. Jurnal Pengabdian 
Pada Masyarakat, 3(2), 135140.

https://doi.org/10.30653/002.201 832.61, 2018.

Kiftiyah, I. N., Sagita, S., \& Ashar, A.

B. Peran Media Youtube Sebagai Sarana Optimalisasi Perkembangan Kognitif pada Anak Usia Dini. Prosiding Seminar Nasional Penguatan Individu Di Era Revolusi Informasi, 1998, 199-208, 2006. Mahardhika, G. P. Digital game based learning dengan model ADDIE untuk pembelajaran doa seharihari. Teknoin, 21(2), 115-122. https://doi.org/10.1007/s13398014-0173-7.2, 2015.

Sudaryono, Desrianti, D. I., \& Maulida, S. N. Media Komik Interaktif untuk Anak Usia Dini pada RA Yasir Tangerang. ICIT Journal, 4(2), 168-179.

https://doi.org/https://10.33050/i cit.v4i2.91, 2018.

Yasa, P. A. D., Sunarya, I. M. G., \& Wirawan, I. M. A. (2015). Pengembangan Film Komik 3 Dimensi "Ayo Kita Mengenal Binatang " untuk Anak-Anak di TK Laksamana Singaraja. Karmapati, 4, 2015

Yaswinda, Nilawati, E., \& Hidayati, A. Pengembangan Media Video
Tutorial Pembelajaran Sains Berbasis Multisensori Ekologi untuk Meningkatkan Kogntif Anak Taman Kanak-Kanak. Jurnal AUDI, 3359(2), 100-109, 2019.

Zahro, I. F., Atika, A. R., \& Westhisi, S. M. Strategi Pembelajaran Literasi Sains Untuk Anak Usia Dini. Jurnal Ilmiah Potensia, 4(2), 121-130, 2019. 